\title{
On the types of papers the Asia Pacific Journal of Management generally publishes
}

\author{
David Ahlstrom
}

Published online: 28 January 2012

(C) Springer Science+Business Media, LLC 2012

At the Asia Pacific Journal of Management (APJM) we receive many queries from prospective authors about how to publish in $A P J M$ and the types of papers published. In response, we have been running a series of articles in $A P J M$ from 2010 to 2012 to assist prospective authors in that endeavor. In 2010, APJM published three editorial articles with some general recommendations on publishing in the journal and how to avoid some common mistakes that normally lead to a rejection at the editor's desk (Ahlstrom, 2010a, b, c). In 2011 we published several more articles that can help authors to understand APJM's general aims and scope (Ahlstrom, 2011a), some tips on organizing a paper (Ahlstrom, 2011b), and a summary of helpful sources for authors on key parts of a paper such as the literature review or the contributions section (Ahlstrom, 2011c). This editorial article will provide a quick reference to those works and answer the second part of the above author query about the types of papers typically published at $A P J M$, as well as some we would like to receive a little more often.

\section{What does APJM generally publish?}

This topic was initially addressed in the editorial article in issues 1 and 2 of 2010 (Ahlstrom, 2010a, b). Those articles summarized topics such as avoiding a desk

\footnotetext{
The Asia Pacific Journal of Management would like to announce that our publisher, Springer Publishing, has renamed our Best Paper Award the Mike Peng Best Paper Award, in recognition of our former Editorin-Chief Mike Peng. Mike was a Senior Editor at APJM from 2004 to 2006 and Chief Editor from 2007 through 2009. He has continued to work regularly with $A P J M$ as a Consulting Editor as well as guest editing multiple special issues. Mike's indefatigable assistance to APJM has helped to fuel its success as reflected in part by our first Social Sciences Citation Index Impact Factor 3.36 and large increases in our submissions and downloaded article counts. Thanks for this are also due to all of APJM's Senior Editors, the Editorial Advisory and Review Boards, the reviewers, authors, and our managing and copy editors, Rachel (Rae) Pinkham in Texas, USA, Saraswathi (Sara) Ramaswamy in Chennai, India, and Jurgen Torres, in Manila, Philippines. Thanks also go to Marc Ahlstrom of BCC for his editorial and research assistance.
}

D. Ahlstrom $(\bowtie)$

Department of Management, The Chinese University of Hong Kong, Shatin, NT, Hong Kong e-mail: ahlstrom@baf.msmail.cuhk.edu.hk 
rejection, writing for a research-oriented audience, and useful tactics for authors. As those articles noted, APJM publishes a variety of topics, theories, and research designs within the journal's aims and scope (Ahlstrom, 2010a, 2011a). These include theory papers such as those found in the Academy of Management Review, and empirical papers of the general organization and rigor that might be found in the Academy of Management Journal or the Journal of International Business Studies. APJM publishes a range of papers, from macro to micro, from theory-building to theory-testing and theory-improvement, both quantitative and qualitative. This summary is not exhaustive; simply because a type of paper has not been published in APJM before does not mean that it will not be considered for publication. It bears repeating that the editors also welcome conceptual articles that may fit in the Perspectives or Commentary sections of the journal, as well as review articles that are generally consistent with those found in the Journal of Management and other well ranked journals (e.g., Capon, Farley, \& Hoenig, 1990).

Also in terms of what APJM publishes, prospective authors must remember that $A P J M$ is primarily a management journal. We try to be open to a wide range of theoretical orientations and disciplines and we sometimes do publish papers written by authors from other disciplines such as finance and accounting, or production and information systems, for example. Yet often, we receive manuscripts that have the word "management" or "managerial" in the title (such as "...managerial accounting," or "managing your network's traffic flow"), but contain little else about the management discipline or management research. The authors are commonly surprised when these papers (often well constructed) are rejected. The reason for this is APJM does not publish papers that are focused exclusively (or near-exclusively) on making contributions to other disciplines, such as finance and accounting, economics, or production and operations management, to name a few such manuscript topics (Ahlstrom, 2010b, c). We expect that submissions to APJM will address theory in management and organizations, which include the broad array of interests represented in the academic management community. Papers that utilize some theory and methods from finance to address governance issues or marketing to inform entrepreneurship, for example, would possibly be representative of research at the intersection of management and allied disciplines and could be suitable for APJM (e.g., Aaker, 2007; Arthur, 1996; Davidsson \& Wiklund, 1997; Raman \& Fisher, 1996). But simply including the word "manage" or "management" in the manuscript's title does not qualify it as a management paper. The research question asked, the dependent variable explained, the contributions of the paper, and its research site are all crucial to whether a manuscript might be suitable for APJM and fit the journal's aims and scope (Ahlstrom, 2010b, 2011a).

\section{Theory is important}

APJM also receives a significant number of submissions that are largely atheoretical. These papers sometimes seek to explain a topic such as the steps in total quality management (TQM) or describing consumer behavior in a particular country. APJM similarly receives a number of methods-driven papers explaining, for instance, a particular production phenomenon or focusing on the application of a method such as 
data envelopment analysis (DEA). These topics are certainly interesting and these papers are often fairly rigorous. But currently, APJM does not publish "how to" articles directed mainly at managers or broad textbook-like chapters on a production or analysis method (Ahlstrom, 2011a). This is not to say that TQM, production-operations manuscripts, or DEA analyses are not welcome at APJM (Ahlstrom, 2010c, 2011a). ${ }^{1}$ But it is important for authors to understand that at $A P J M$ we encourage papers that ask (and answer) research questions that help to build, test, and improve management and organization theory, not teach managers and supervisors DEA, TQM, or consumer behavior in a particular industry. A paper's primary focus must be on theory: theory building, theory testing, or theory improvement, which addresses questions primarily of interest to management researchers (Christensen \& Raynor, 2003; Peng \& Dess, 2010; Sutton \& Staw, $1995){ }^{2}$ It should be quickly added that although theory is very important at APJM, it is not the only contribution that a paper should make. Manuscripts should also suggest contributions to practice, and if data are collected, some empirical contribution should also be provided. Others include contributions to research design and methods (Ahlstrom, 2011b; Ahlstrom, Lamond, \& Ding, 2009; Peng, 2004). Nevertheless theory is quite important and authors should be careful to specify their theoretical lens and explain the paper's contributions to theory (Colquitt \& Ireland, 2009; Corley \& Gioia, 2011). For more guidance on writing up your paper's contributions, see Ahlstrom, (2011c) for some more helpful sources.

\section{Review articles}

APJM receives numerous manuscripts that essentially introduce and summarize work from other fields such as risk management, which is generally a finance topic, or consumer behavior, which is a marketing topic, just to name two. APJM certainly is interested in publishing review articles, though they should focus on theory and research in the management area, or otherwise provide significant contribution to management researchers and scholars. A suitable review article is not the literature review chapter of an author's dissertation, nor should it be a simple walk-through of a literature on a given topic. Reviews should summarize the literature, provide some contribution and helpful observations about that literature's development and organization, any internal (or cross-discipline) linkages, and suggest some future research emerging from the review (Ahlstrom, 2010c; Ismail \& Ford, 2010).

Good examples of review articles can be found in many places. The Journal of Management $(J O M)$ is a particularly good source as it regularly publishes review

\footnotetext{
${ }^{1}$ The main focus (aims and scope) at $A P J M$ is to publish theory-based research that advances the understanding of management and organizational success with emphasis on the Asia Pacific region of the world. If a paper's main focus is about presenting a methodology or studying consumer behavior, for example, these would lie outside of APJM's aims and scope (Ahlstrom, 2011a). A methods paper could certainly be welcome, but it would have to be of interest to management researchers, not practicing managers.

${ }^{2}$ Phenomenological papers that are basically exploratory and help to identify new theory are certainly welcome (cf. Hambrick, 2007). But as noted, authors should be careful that they have understood and reviewed the literature on the topic such that an exploratory paper is warranted by the lack of research or fuzzy categories in that literature.
} 
articles. A recent review article in $J O M$ asked about the criteria that should be used in evaluating the effects of leadership (Hiller, DeChurch, Murase, \& Doty, 2011). In this review article, the authors summarized the ways leadership research has answered questions about leadership's effects on various performance outcomes (Hiller et al., 2011; Kaiser, Hogan, \& Craig, 2008). Recent review articles in APJM include Sun, Zhao, and Yang (2010) on executive compensation in Asia and Nakamura (2011) on governance in Japan. Also, some interesting reviews have been written on research in a focused research area such as foreign businesses in China (Yang, Tipton, \& Li, 2011) and on a relatively new research site, such as India (Lahiri, 2011). Also for another firm performance-related review paper, see the forthcoming article in APJM on corporate boards and performance (van Essen, van Oosterhout, \& Carney, 2012). A good review article that also uses meta-analysis to review a major strategy topic is a 1990 Management Science article on determinants of firm financial performance (Capon et al., 1990). That Management Science article by Noel Capon and his colleagues also has a helpful figure that quickly summarizes the effects of various strategy variables on firm performance. This is a good model for authors who need to provide a quick summary of an extensive literature to support the written part of the literature review. Authors interested in doing a review should study review articles from APJM, JOM, and other good management journals. ${ }^{3}$

\section{Perspectives articles}

APJM also publishes regular perspectives articles. These may also review the literature, but then they take up a particular aspect of the topic such as a debate or something that needs more testing or better definitions or classifications. In 2006, Senior Editor Klaus Meyer (2006) wrote a perspectives paper about Asian management research and how researchers in this area need more confidence in the topics. Meyer could not obviously review everything on Asian management research, so he selected certain topical areas to discuss his main thesis. That article later won the 2008 APJM Best Paper Award. APJM's former Editor-in-Chief Mike Peng has also written a number of fine perspectives articles for the journal (e.g., Jiang \& Peng, 2011; Peng, 2005; Zhou \& Peng, 2010); his 2005 publication won APJM's Best Paper Award in 2010. ${ }^{4}$ Other fine perspectives papers include Ming-Jer Chen's (2010) article in APJM on the process of doing competitive dynamics research, and Bhagat, McDevitt, and McDevitt's (2010) article on improving the robustness of Asian management theories.

\footnotetext{
${ }^{3}$ For a good summary of an extensive literature with an accompanying table to support that summary, see Hayton, George, and Zahra (2002) in Entrepreneurship: Theory \& Practice.

${ }^{4}$ Mike Peng's (2005) paper "From China strategy to global strategy" won APJM's Best Paper Award for 2010, which was announced and presented at the Asia Academy of Management Conference in Macau in December of 2010. An empirical paper, "The effects of emotional intelligence on job performance and life satisfaction for the research and development scientists in China" (Law, Wong, Huang, \& Li, 2008) was just given the Best Paper Award for 2011, which the publisher of APJM, Springer, has renamed the Mike Peng Best Paper Award.
} 


\section{Commentary articles}

APJM also publishes commentary articles. Commentaries are usually thought of as commenting on a previous or current article in the journal, with both objective and subjective points made. APJM sometimes publishes commentaries on a particular article such as Sheila Puffer and Daniel McCarthy's (2007) commentary on the aforementioned paper by Klaus Meyer on the confidence in Asian research, or Tony Fang's (2010) well-cited paper commenting in part on Hofstede's work as it is used in Asian research (Hofstede, 1984, 2007; Hofstede \& Hofstede, 2005).

A commentary paper in APJM may also help to make sense of a topic, theory, or research design and approach in management or international business (Meyer, 2009). In APJM's Special Issue on Managing in Ethnic Chinese Communities (Ahlstrom, Chen, \& Yeh, 2010), Lin and Si (2010) wrote a commentary on how guanxi, or connections, which are usually thought of as an asset in China (and other countries), can also create problems for firms, much as the international relations literature has shown how alliances can sometimes confer costs to countries by dragging them into unwanted actions or conflicts (e.g., Reiter \& Gartner, 2001). $A P J M$ hopes to receive and publish more helpful commentaries or exchanges on research topics that also have practical import for managers and organizations (e.g., Latham \& Locke, 2009; Locke \& Latham, 2009).

\section{Future articles}

The examples above illustrate what APJM has generally published. This, however, is not meant to be an exhaustive list. At $A P J M$ we welcome a range of papers including empirical hypothesis-testing (variance) papers and rigorously done qualitative empirical papers, which build, test, and improve theory in management (Ahlstrom, 2011a; Christensen, 2006). APJM typically does not publish single company case studies that are written for the purpose of classroom instruction, but certainly welcomes rigorously written case studies, narratives, ethnographies and other interpretive papers that identify new theory or present very interesting observations that might contribute to theory and practice in management and organizations (Christensen \& Carlile, 2009; Walsham, 2006). We hope to receive additional conceptual, qualitative methods, experiments, perspectives, and commentary papers, as well as some nontraditional research topics that are helpful to management scholars (e.g., Ahlstrom et al., 2009; Huang, 2010; Li, 2011; Locke \& Latham, 2009; Meyer, 2009). For additional information on the aims and scope of $A P J M$, organizing and formatting papers, and some helpful sources for authors, see my editorial articles in APJM in 2010 and 2011 (Ahlstrom, 2010b, $2011 \mathrm{a}, \mathrm{b}, \mathrm{c})$ and the many helpful works cited here and in those articles.

\section{References}

Aaker, D. 2007. Innovation: Brand it or lose it. California Management Review, 50(1): 8-24.

Ahlstrom, D. 2010a. Publishing in the Asia Pacific Journal of Management. Asia Pacific Journal of Management, 27(1): 1-8. 
Ahlstrom, D. 2010b. Clearing the first hurdle at the Asia Pacific Journal of Management. Asia Pacific Journal of Management, 27(2): 171-177.

Ahlstrom, D. 2010c. Avoiding common missteps: Writing papers suitable for the Asia Pacific Journal of Management. Asia Pacific Journal of Management, 27(4): 583-586.

Ahlstrom, D. 2011a. On the aims and scope of the Asia Pacific Journal of Management: What does APJM really seek to publish?. Asia Pacific Journal of Management, 28(2): 215-219.

Ahlstrom, D. 2011b. A checklist for prospective authors of Asia Pacific Journal of Management. Asia Pacific Journal of Management, 28(3): 449-452.

Ahlstrom, D. 2011c. Some helpful sources for prospective authors in Asia Pacific Journal of Management. Asia Pacific Journal of Management, 28(4): 661-665.

Ahlstrom, D., Lamond, D., \& Ding, Z. 2009. Reexamining some management lessons from military history. Asia Pacific Journal of Management, 26(4): 617-642.

Ahlstrom, D., Chen, S.-j., \& Yeh, K. S. 2010. Managing in ethnic Chinese communities: Culture, institutions, and context. Asia Pacific Journal of Management, 27(3): 341-354.

Arthur, W. B. 1996. Increasing returns and the new world of business. Harvard Business Review, 74(4): $100-109$.

Bhagat, R. S., McDevitt, A. S., \& McDevitt, I. 2010. On improving the robustness of Asian management theories: Theoretical anchors in the era of globalization. Asia Pacific Journal of Management, 27(2): 179-192.

Capon, N., Farley, J. U., \& Hoenig, S. 1990. Determinants of financial performance: A meta-analysis. Management Science, 36(10): 1143-1159.

Chen, M.-J. 2010. Reflecting on the process: Building competitive dynamics research. Asia Pacific Journal of Management, 27(1): 9-24.

Christensen, C. M. 2006. The ongoing process of building a theory of disruption. Journal of Product Innovation Management, 23(1): 39-55.

Christensen, C. M., \& Carlile, P. R. 2009. Course research: Using the case method to build and teach management theory. Academy of Management Learning \& Education, 8(2): 240-251.

Christensen, C. M., \& Raynor, M. E. 2003. Why hard-nosed executives should care about management theory. Harvard Business Review, 81(9): 66-74.

Colquitt, J. A., \& Ireland, R. D. 2009. From the editors: Taking the mystery out of AMJ's reviewer evaluation form. Academy of Management Journal, 52(2): 224-228.

Corley, K. G., \& Gioia, D. A. 2011. Building theory about theory building: What constitutes a theoretical contribution?. Academy of Management Review, 36(1): 12-32.

Davidsson, P., \& Wiklund, J. 1997. Values, beliefs and regional variations in new firm formation rates. Journal of Economic Psychology, 18: 179-199.

Fang, T. 2010. Asian management research needs more self-confidence: Reflection on Hofstede (2007) and beyond. Asia Pacific Journal of Management, 27(1): 155-170.

Hambrick, D. 2007. The field of management's devotion to theory: Too much of a good thing?. Academy of Management Journal, 50: 1346-1352.

Hayton, J. C., George, G., \& Zahra, S. A. 2002. National culture and entrepreneurship: A review of behavioral research. Entrepreneurship: Theory \& Practice, 26(4): 33-52.

Hiller, N. J., DeChurch, L. A., Murase, T., \& Doty, D. 2011. Searching for outcomes of leadership: A 25year review. Journal of Management, 37(4): 1137-1177.

Hofstede, G. 1984. Cultural dimensions in management and planning. Asia Pacific Journal of Management, 2(1): 81-99.

Hofstede, G. 2007. Asian management in the 21st century. Asia Pacific Journal of Management, 24(4): 411-420.

Hofstede, G., \& Hofstede, G. J. 2005. Cultures and organizations: Software of the mind: Intercultural cooperation and its importance for survival. New York: McGraw-Hill.

Huang, Y. 2010. Debating China's economic growth: The Beijing Consensus or the Washington Consensus?. Academy of Management Perspectives, 24(2): 31-47.

Ismail, K. M., \& Ford, D. L., Jr. 2010. Organizational leadership in Central Asia and the Caucasus: Research considerations and directions. Asia Pacific Journal of Management, 27(2): 321-340.

Jiang, Y., \& Peng, M. W. 2011. Principal-principal conflicts during crisis. Asia Pacific Journal of Management, 28(4): 683-695.

Kaiser, R. B., Hogan, R., \& Craig, S. B. 2008. Leadership and the fate of organizations. American Psychologist, 63(2): 96-110.

Lahiri, S. 2011. India-focused publications in leading international business journals. Asia Pacific Journal of Management, 28(2): 427-447. 
Latham, G. P., \& Locke, E. A. 2009. Science and ethics: What should count as evidence against the use of goal setting?. Academy of Management Perspectives, 23(3): 88-91.

Law, K. S., Wong, C.-S., Huang, G.-H., \& Li, X. 2008. The effects of emotional intelligence on job performance and life satisfaction for the research and development scientists in China. Asia Pacific Journal of Management, 25(1): 51-69.

Li, Y. 2011. Emotions and new venture judgment in China. Asia Pacific Journal of Management, 28(2): $277-298$.

Lin, J., \& Si, S. X. 2010. Can guanxi be a problem? Contexts, ties, and some unfavorable consequences of social capital in China. Asia Pacific Journal of Management, 27(3): 561-581.

Locke, E. A., \& Latham, G. P. 2009. Has goal setting gone wild, or have its attackers abandoned good scholarship?. Academy of Management Perspectives, 23(1): 17-23.

Meyer, K. E. 2006. Asian management research needs more self-confidence. Asia Pacific Journal of Management, 23(2): 119-137.

Meyer, K. E. 2009. Motivating, testing, and publishing curvilinear effects in management research. Asia Pacific Journal of Management, 26(2): 187-193.

Nakamura, M. 2011. Adoption and policy implications of Japan's new corporate governance practices after the reform. Asia Pacific Journal of Management, 28(1): 187-213.

Peng, M. W. 2004. Outside directors and firm performance during institutional transitions. Strategic Management Journal, 25: 453-471.

Peng, M. W. 2005. From China strategy to global strategy. Asia Pacific Journal of Management, 22(2): $123-141$.

Peng, M. W., \& Dess, G. G. 2010. In the spirit of scholarship. Academy of Management Learning and Education, 9(2): 282-298.

Puffer, S. M., \& McCarthy, D. J. 2007. Does Asian management research need more self-confidence? Reflections from Russia. Asia Pacific Journal of Management, 24(4): 509-517.

Raman, A., \& Fisher, M. 1996. Reducing the cost of demand uncertainty through accurate response to early sales. Operations Research, 44(4): 87-99.

Reiter, E., \& Gartner, H. (Eds.). 2001. Small states and alliances. Heidelberg, DE: Physica-Verlag.

Sun, S. L., Zhao, X., \& Yang, H. 2010. Executive compensation in Asia: A critical review and outlook. Asia Pacific Journal of Management, 27(4): 775-802.

Sutton, R., \& Staw, B. 1995. What theory is not. Administrative Science Quarterly, 40: 371-384.

van Essen, M., van Oosterhout, J. H., \& Carney, M. 2012. Corporate boards and the performance of Asian firms: A meta-analysis. Asia Pacific Journal of Management. doi:10.1007/s10490-011-9269-1.

Walsham, G. 2006. Doing interpretative research. European Journal of Information Systems, 15: 320-330.

Yang, J. Y., Tipton, F. B., \& Li, J. T. 2011. A review of foreign business management in China. Asia Pacific Journal of Management, 28(3): 627-659.

Zhou, J. Q., \& Peng, M. W. 2010. Relational exchanges versus arm's-length transactions during institutional transitions. Asia Pacific Journal of Management, 27(3): 355-370.

David Ahlstrom ( $\mathrm{PhD}$, New York University) is a professor at The Chinese University of Hong Kong. His research interests include managing in Asia, innovation and entrepreneurship, and management history. Professor Ahlstrom has published over 70 peer-reviewed articles in journals such as the Strategic Management Journal, Academy of Management Review, Journal of International Business Studies, Academy of Management Perspectives, Journal of Business Venturing, and the Journal of Management Studies. He also co-authored the textbook International Management: Strategy and Culture in the Emerging World and guest edited two Special Issues of Entrepreneurship: Theory \& Practice. Professor Ahlstrom has also guest edited two Special Issues of APJM: Turnaround in Asia in 2004 and Managing in Ethnic Chinese Communities in 2010, and was Senior Editor of APJM during 2007-2009, before having served as its Editor-in-Chief from 2010-2012. 